JIKAP PGSD: Jurnal Ilmiah Ilmu Kependidikan

Vol,1. No,1. Tahun 2017

e-ISSN: 2597-4440 dan p-ISSN: 2597-4424

This work is licensed under a Creative Commons Attribution

4.0 International License

\title{
Penerapan Model Pembelajaran Think Pair Share (Tps) Dalam Meingkatkan Hasil Belajar Matemtika Siswa Kelas Iv Sd Negeri 14 Biru Kecamatan Tanete Riattang Kabupaten Bone
}

\author{
Mei Wulangdari ${ }^{1}$, Awaluddin Muin ${ }^{2}$ \\ ${ }^{1}$ Fakultas Ilmu Pendidikan, UNM \\ Email: meiwulangdari20@gmail.com \\ ${ }^{2}$ Fakultas Ilmu Pendidikan, UNM
}

\begin{abstract}
Abstrak. Penelitian ini bertujuan untuk meningkatkan hasil belajar matematika melalui model pembelajaran Think Pair Share (TPS) pada siswa kelas IV SD Negeri 14 Biru Kecamatan Tanete Riattang kabupaten Bone. Hasil belajar siswa pada materi operasi hitung penjumlahan dan penguarangan pecahan masih banyak dibawah KKM yang ditetapkan yaitu 75. Hal ini disebabkan oleh faktor yang berasal dari guru yaitu: (1) penyajian materi masih bersifat monoton, (2) kurangnya penguasaan kelas, (3) Perhatian guru terhadap siswa kurang, yakni hanya terfokus pada beberapa siswa saja, (4) kurang kreatif memilih media pembelajaran. Sementara dari aspek siswa terlihat bahwa selama proses belajaran matematika,(1) siswa merasa bosan selama proses pembelajaran, (2) siswa menjadi ribut, (3) Siswa lainnya dibiarkan melakukan aktivitas apa saja yang diinginkan, (4) siswa kurang semangat dalam proses belajar mengajar. Oleh sebab itu peneliti berupaya untuk memecahkan masalah melalui penerapan model pembelajaran Think Pair Share (TPS). Jenis penelitian ini adalah penelitian tindakan kelas (PTK) yang terdiri dari perencanaan, pelaksanaan, observasi dan refleksi. Fokus penelitian adalah penerapan model pembelajaran Think Pair Share (TPS) dan hasil belajar siswa dalam pembelajaran matematika. Subjek dalam penelitian ini adalah siswa kelas IV yang aktif dan terdaftar pada semester genap tahun ajaran 2016/2017 yang terdiri atas 24 siswa, 11 siswa laki-laki dan 13 siswa perempuan. Teknik pengumpulan data dalam penelitian ini adalah dilakukan obeservasi, tes dan dokumentasi. Sedangkan teknik analisis data dalam penelitian ini yaitu 1) mereduksi data, 2) penyajian data dan 3) penarikan kesimpulan. Hasil penelitian yang telah dianalisi, menunjukkan bahwa terjadi peningkatan hasil belajar siswa dari siklus I dengan kategori cukup (C) meningkat menjadi kategori baik (B) pada siklus ke II. Hasil analisis data disimpulkan bahwa model pembelajan Think Pair Share (TPS) dapat meningkatkan hasil belajar siswa dalam pembelajaran matematika di kelas IV SD Negeri 14 Biru Kecamatan Tanete Riattang Kabupaten Bone.
\end{abstract}

Kata Kunci: model pembelajaran Think Pair Share (TPS), pecahan, operasi penjumlahan, operasi pengurangan

\begin{abstract}
This study aims to improve the learning outcomes of mathematics through Think Pair Share (TPS) learning model in fourth grade students of SD Negeri 14 Biru Tanete Riattang Sub-district Bone District. Students' learning outcomes on material count arithmetic addition and fractional breaking is still much below the established KKM that is 75. This is caused by factors derived from the teacher are: (1) the presentation of the material is still monotonous, (2) the lack of mastery of the class, (3) The teacher's attention to the students is less, that is only focused on some students only, (4) instructional Media. Meanwhile, from the aspect of the students, it can be seen that during the learning process of mathematics, (1) the students feel bored during the learning process, (2) the students become noisy, (3) other students are allowed to do whatever activities they want, (4) teach.
\end{abstract}


Therefore researchers attempt to solve problems through the application of Think Pair Share (TPS) learning model. This type of research is a classroom action research (PTK) consisting of planning, implementation, observation and reflection. The focus of the research is the application of Think Pair Share (TPS) learning model and student learning outcomes in mathematics learning. Subjects in this study were active fourth graders and enrolled in the even semester of the academic year 2016/2017 consisting of 24 students, 11 male students and 13 female students. Technique of collecting data in this research is done obeservasi, tes and documentation. While data analysis technique in this research that is 1) reducing data, 2) data presentation and 3) drawing conclusion. The results of the research have been analyzed, indicating that there is an increase in student learning outcomes from cycle I with enough category (C) increased to either category (B) on the second cycle. Results of data analysis concluded that the model of Think Pair Share (TPS) can improve student learning outcomes in learning mathematics in class IV SD Negeri 14 Biru Tanete Riattang sub-district Bone District.

Keywords: Think Pair Share (TPS) learning model, fractional, addition operation, reduction operation

\section{PENDAHULUAN}

Pembelajaran matematika ditingkat sekolah dasar mempunyai kedudukan yang penting dalam mencapai tujuan pendidikan yang telah ditetapkan, matematika merupakan mata pelajaran inti disetiap jenjang sekolah, sehingga sekolah dipandang sebagai tempat yang sangat strategis untuk menghasilkan sumber daya manusia yang berkualitas, agar mampu menguasai, menggunakan dan mengembangkan Ilmu Pengetahuan dan Teknologi (IPTEK). Bukti bahwa matematika merupakan bidang studi yang memiliki peranan penting dalam pendidikan adalah pelajaran matematika diberikan kepada semua jenjang pendidikan mulai dari sekolah dasar sampai perguruan tinggi. Menurut Aisyah, dkk (2008: 3) mengatakan bahwa "matematika merupakan ilmu universal yang mendasari perkembangan teknologi modern, mempunyai peran dalam berbagi disiplin dan menunjukkan daya pikir manusia".

Pembelajaran bukan hanya untuk mengetahui dan memahami apa yang terkandung dalam matematika itu sendiri, tetapi lebih menekankan pada pola berfikir siswa agar dapat memecahkan masalah secara rasional, kritis, logis, kreatif, cermat, dan teliti. Menurut Depdiknas (Susanto, 2013: 190), tujuan pembelajaran matematika di sekolah dasar adalah agar siswa memiliki kemampuan untuk : (1) Memahami konsep matematika, menjelaskan keterkaitan antarkonsep dan mengaplikasikan konsep atau alogaritma,

(2) menggunakan penalaran pada pola dan sifat, melakukan manipulasi matematika dalam membuat generalisai, menyusun bukti, atau menjelaskan gagasan dan pernyataan matematika, (3) memecahkan masalah yang meliputi kemampuan memahami masalah, merancang model matematika, menyelesaikan model dan menafsirkan solusi yang diperoleh, (4) mengkomunikasikan gagasan dengan simbol, tebel, diagram, atau media lain untuk memperjelas keadaan atau masalah, (5) memiliki sikap menghargai kegunaan matematika dalam kehidupan sehari-hari.

Untuk mencapai tujuan pembelajaran matematika tersebut dalam pelaksanaannya diperlukan tenaga pendidik yang terampil merancang dan mengelolah pembelajaran yang mengarah pada ranah kognitif, afektif dan psikomotor siswa, agar dapat mengajarkan matematika dengan baik. Penerapan model pembelajaran yang aktif, kreatif, inovatif dan menyenangkan dalam pembelajaran dapat membuat siswa terlibat aktif, selain itu penerapan model pembelajaran tersebut dapat memberikan pengalaman berarti pada siswa, sehingga siswa menyukai dan senang belajar matematika.

Berdasarkan kenyataan guru dalam menyajikan materi matematika melakukan pembelajaran langsung, yaitu guru langsung menuliskan rumus-rumus matematika kemudian menugaskan siswa dalam pemecahan masalah. Selain itu, guru kurang memberikan bukti atau contoh yang nyata yang berkaitan dalam kehidupan siswa, dan guru kurang mengaktifkan siswanya dalam memanipulasi alat peraga atau media pembelajaran, alasannya membuangbuang waktu saja dan jika ditinjau dari segi hasil akan sama, jadi dalam pembelajaran matematika 
terkesan guru lebih banyak mendominasi kegiatan pembelajarn. Proses tersebut kurang tepat diterapkan pada pembelajaran matematika di sekolah dasar, karena akan menghalangi kreativitas siswa dalam mengembangkan daya berpikirnnya, sedangkan materi matematika yang dipelajari di sekolah dasar merupakan kelanjutan materi untuk jenjang pendidikan selanjutya..

Pembelajaran yang dijelaskan diatas sering terjadi di setiap sekolah, namun pada kenyataannya hal tersebut kurang mendapat apresiasi dari pihak guru dan pihak siswa, hal ini juga terjadi di SD Negeri 14 Biru Kecamatan Tanete Riattang Kabupaten Bone di kelas IV. Peneliti melakukan pengamatan aspek guru dan aspek siswa untuk mengetahui penyebab rendahnya hasil belajar. Dari aspek guru dalam pembelajaran matematika terungkap bahwa: (1) penyajian materi masih bersifat monoton, (2) kurangnya penguasaan kelas, (3) Perhatian guru terhadap siswa kurang, yakni hanya terfokus pada beberapa siswa saja, (4) kurang kreatif memilih media pembelajaran. Sementara dari aspek siswa terlihat bahwa selama proses belajaran matematika,(1) siswa merasa bosan selama proses pembelajaran, (2) siswa menjadi ribut, (3) Siswa lainnya dibiarkan melakukan aktivitas apa saja yang diinginkan, (4) siswa kurang semangat dalam proses belajar mengajar.

Model pembelajaran yang dapat diterapkan sebagai alternatif dalam pemecahan masalah di atas, yaitu model pembelajaran Think Pair Share (TPS). Model ini memperkenalkan ide waktu berfikir atau waktu tunggu, yang merupakan faktor kuat dalam melakukan proses belajar mengajar. Guru tidak lagi mendominasi seperti lazimnya pada saat ini, seperti dikatakan oleh (Trianto, 2009: 81) model pembelajaran Think Pair Share (TPS) "memberi siswa waktu lebih banyak untuk berfikir, untuk merespon, dan saling membantu". Menurut Huda (2013:206) model pembelajaran Think Pair Share (TPS) memiliki manfaat yaitu: 1) Memungkinkan siswa untuk bekerja sendiri dan bekerja sama dengan orang lain, 2) Mengoptimalkan partisipasi siswa, dan selain itu, 3) Memberikan kesempatan kepada siswa untuk menunjukkan partisipasi mereka kepada orang lain.

Berdasarkan uraian di atas, maka peneliti akan melakukan sebuah Penelitian Tindakan Kelas (PTK) dengan judul "Penerapan Model Pembelajaran Think Pair Share (TPS) dalam Meningkatkan Hasil Belajar Matematika Siswa
Kelas IV SD Negeri 14 Biru Kecamatan Tanete Riattang Kabupaten Bone".

1. METODE PENELITIAN

a. Pendekatan Penelitian

Penelitian ini dilakukan dengan menggunakan pendekatan kualitatif bersifat deskriptif, pendekatan kualitatif dalam penelitian ini digunakan untuk menelusuri dan mendapatkan gambaran secara jelas tentang fenomena yang tampak selama pembelajaran berlangsung. Menurut pendapat Satori (2009: 25), penelitian kualitatif adalah suatu pendekatan penelitian yang mengungkap situasi sosial tertentu dengan mendekripsikan kenyataan secara benar, dibentuk oleh kata-kata berdasarkan teknik pengumpulan dan analisis data yang relevan yang diperoleh dari situasi yang alamiah.

b. Jenis Penelitian

Jenis penelitian yang digunakan dalam penelitian ini adalah penelitian tindakan kelas (PTK). Menurut pendapat Daryanto (2011: 4) bahwa: "PTK adalah penelitian yang dilakukan oleh guru didalam kelasnya sendiri melalui refleksi diri dengan tujuan untuk memperbaiki kualitas proses pembelajaran dikelas, sehingga hasil belajar siswa dapat ditingkatkan". Ada empat tahapan penting dalam penelitian tindakan kelas yang diungkapkan oleh Arikunto, dkk. (2011: 20) yaitu: "(1) perencanaan, (2) pelaksanaan, (3) pengamatan, dan (4) refleksi". Hubungan antara keempat tahapan tersebut diatas, menunjukkan siklus berulang, apabila siklus pertama gagal, maka akan diadakan perbaikan dengan melaksanakan siklus berikutnya.

\section{c. Fokus Penenlitain}

Adapun yang menjadi fokus dalam penelitian ini yaitu:

1. Penerapan model pembelajaran Think Pair Share (TPS) merupakan suatu model pembelajaran yang menekankan kerja kelompok dalam belajar yang terdiri atas 3 langkah-langkah yaitu: berpikir (thinking), berpasangan (pairing) dan berbagi (sharing), untuk lebih jelasnya akan diuraikan sebagi berikut:

2. Hasil belajar matematika yang dimaksud adalah kemampuan yang dimiliki oleh siswa setelah melakukan aktivitas belajar yang berupa kemampuan kognitif dan afektif pada peningkatan hasil belajar pada mata pelajaran matematika.

d. Setting Penelitian 
Subjek dalam penelitian ini adalah siswa kelas IV SD Negeri 14 Biru Kecamatan Tanete Riattang Kabupaten Bone yang aktif dan terdaftar pada semester genap tahun ajaran 2016/2017 yang terdiri atas 24 siswa, 11 siswa laki-laki dan 13 siswa perempuan, dengan sasaran utama meningkatkan hasil belajar siswa melalui penerapan model pembelajaran Think Pair Share (TPS).

e. Rancangan Tindakan

Penelitian ini menggunakan tahapan penelitian tindakan kelas yaitu penelitian yang terdiri dari dua siklus dimana dalam satu siklus terdiri dari empat tahapan. Menurut Arikunto, dlk (2011: 16) bahwa pelaksanaan tindakan dalam PTK meliputi 4 tahap, yaitu (1) perencanaan (planing), (2) pelaksanaan (acting), (3) pengamatan (observing), dan (4) refleksi (reflecting).

f. Teknik Pengumpulan data

Untuk pengumpulan data dalam penelitian ini di lakukan dengan observasi, tes dan dokumnetasi.

\section{g. Analisis Data}

Tekhnik analisis data yang digunakan bersifat kualitatif. Analisis data dalam penelitian inindilakukan selama dan setelah pengumpulan data. Analisis data dilakukan setelah satu siklus pembelajaran dilaksanakan secara keseluruhan. Adapun tahapan yang harus dikerjakan dalam menganalisis data penelitian kualitatif yang terdiri dari tiga tahap kegiatan berurutan, yaitu 1) mereduksi data (data derection) , 2) menyajikan atau memaparkan data (data display), dan 3) menarik kesimpulan serta memverivikasi (conlusion drawing/verifying).

\section{h. Indikator Keberhasilan}

Indikator keberhasilan dalam penelitian ini terdiri dari dua indikator yaitu:

1. Segi proses aktivitas guru ditandai dengan penenrapan langkah-langkah model pembelajaran Think Pair Share (TPS) pada mata pelejaran matematika dan aktivitas siswa ditandai dengan keaktifan siswa yang terlihat dalam pelaksanaan pembelajaran dengan menerapkan langkah-langkah model pembelajaran Think Pair Share (TPS) minimal baik.

2. Segi hasil ditandai indikator keberhasilan dengan skor perolehan hasil belajar siswa yang diporeleh dari tes yang diberikan dengan nilai minimal $75 \%$ dari jumlah siswa mencapai Kriteria Ketuntasan Minimal (KKM) yang telah ditetapkan oleh guru untuk mata pelajaran matematika, yaitu 75 .

Adapun kriteria yang digunakan untuk menentukan tingkat kualifikasi perolehan hasil belajar matematika siswa dan keberhasilan proses belajar-mengajar mengacu pada kriteria yang dirumuskan oleh Arikunto dan Safruddin (2009: 35) sebagai berikut

Tabel 3.2 Kriteri Proses dan Hasil Belajar

\begin{tabular}{cr}
\hline Persentase Hasil Belajar & K \\
\hline $75 \%-100 \%$ & $\mathrm{C}$ \\
\hline $49 \%-74 \%$ & $\mathrm{~K}$ \\
\hline$<48 \%$ & $\mathrm{C}$
\end{tabular}

\section{HASIL DAN PEMBAHASAN}

Sebelum melaksanakan kegiatan pembelajaran, peneliti terlebih dahulu melakukan observasi di kelas IV SD Negeri 14 Biru Kecamatan Tanete Riattang Kabupaten Bone. Peneliti memperoleh data awal berpupa nilai UAS ganjil tahun ajaran 2016/2017, pada pembelajaran metematika dengan nilai rata-rata $64,1 \%$ dengan persentase ketuntasan belajar siswa hanya $37,5 \%$ atau 9 siswa yang mencapai nilai KKM yang ditetapkan yaitu 75 dan persentase ketidak tuntasan belajar siswa yaitu $62,5 \%$ atau 15 siswa yang tidak mencapai KKM. Dari data awal tersebut, siswa dalam memahami mata pelajaran matematika masih dikategorikan kurang.

Berdasarkan kenyataan tersebut, maka peneliti menyusun rancangan pembelajaran yang dapat membantu siswa untuk memahami materi matematika dengan menerapkan model pembelajaran Think Pair Share (TPS) yang terdiri dari 6 langkah pembelajaran yaitu: 1) Guru menyajikan materi dengan menggunakan media pembelajaran, 2) guru membagikan lembar kerja siswa dan meminta siswa menggunkan waktu beberapa menit untuk berpikir sendiri jawaban atau masalah, 3) selanjutnya guru meminta siswa untuk berpasangan dan mendiskusikan apa yang telah mereka peroleh, 4) guru meminta pasanganpasangan untuk berbagi dengan keseluruhan kelas yang telah mereka bicarakan, 5) guru memberikan apresiasi kepada setiap pasangan yang telah mengemukakan hasil kerja mereka di depan kelas. 6) guru memberi penjelasan terkait jawaban dari tugas yang telah dikerjakan siswa

Pembelajaran pada siklus I dilakukan dua kali pertemuan, dengan materi pertemuan I yaitu penjumlahan bilangan pecahan biasa 
berpenyebut sama dan pada pertemuan II yaitu penjumlahan bilangan pecahan biasa berpenyebut tidak sama. Untuk memperoleh data pelaksaan pembelajaran siklus I dilakukan observasi, tes dan dokumentasi. Hasil obeservasi dan tes selam pelaksanaan tindakan diperoleh

1. Cara guru menyajika materi pelajaran kurang sistematis.

2. Guru berbicara terlalu cepat pada saat mengarahkan siswa untuk mengerjakan tugas secara individu.

3. Guru belum menggunakan waktu secara efisien.

4. Pada saat guru menjelaskan materi pelajaran masih banyak siswa yang ribut dan bercerita.

5. Pada saat pengerjaan tugas secara individu, siswa terlalu banyak menggunakan waktu.

6. Pada saat mempresentasikan hasil diskusi, siswa terlihat kurang berani dan kurang percaya diri.

Pada tindakan siklus I hasil belajar siswa dalam menyelesaikan tes formatif mencapai rata-rata 70,7 dengan persentase ketuntasan hasil belajar sebesar $62,5 \%$ dan persentase ketidak tuntasan belajar sebesar 37,5\%. Hasil observasi tersebut terlihat masih belum mencapai kriteri keberhasilan yang ditetapkan peneliti yaitu $75 \%$ dengan nilai ketuntasa minimal 75 .

Berdasarkan analisis dan refleksi aktivitas guru dan siswa di atas dan mengacu kepada indikator keberhasilan yang telah ditetapkan oleh peneliti, maka dapat disimpulkan bahwa proses belajar matematika dengan menggunakan model pembelajaran Think Pair Share (TPS) pada siswa kelas IV pada tindakan siklus I belum berhasil, sehingga pembelajaran dilanjutkan pada siklus II.

Pembelajaran tindakan siklus II dilakukan dua kali pertemuan, dengan materi pertemuan I yaitu pengurangan bilangan pecahan biasa berpenyebut sama dan pada pertemuan II yaitu pengurangan bilangan pecahan biasa berpenyebut tidak sama. Dalam pelaksanaan pembelajaran siklus II, keberhasilan sudah mencapai target yang diinginkan, karena guru dan siswa sudah mampu melaksanakan indikator-indikator penerapan model pembelajaran Think Pair Share (TPS) dengan baik. Hasil observasi yang diperoleh yaitu:

1. Guru telah menyajikan materi pelajaran dengan sistematis sehingga siswa mudah memahami materi yang disampaikan.

2. Siswa telah mampu mengarahkan siswa untuk mengerjakan tugas secara individu dengan suara yang keras dan tidak terburu-buru pada saat berbicara.

3. Waktu pembelajaran berlangsung sesuai dengan perencanaan.

4. Siswa telah memperhatikan dengan baik materi yang disampaikan oleh guru.

5. Siswa telah mampu mengerjakan tugas sesuai dnegan waktu yang telah ditentukan.

6. Siswa telah terbiasa belajar dengan menggunakan model pembelajaran Think Pair Share (TPS), sehingga pada saat mempresentasikan hasil diskusi sudah terlihat berani dan percaya diri.

Pada tindakan siklus II hasil belajar siswa dalam menyelesaikan tes formatif telah mencapai rata-rata 80 dengan persentase ketuntasan hasil belajar sebesar 83,3\% dan persentase ketidak tuntasan belajar sebesar $16,7 \%$.

Berdasarkan data hasil tersebut, penelitian tentang peningkatan hasil belajar matematika dengan menerapkan model pembelajaran Think Pair Share (TPS) pada siswa kelas IV SD Negeri 14 Biru Kecamatan Tanete Riattang Kabupaten Bone telah berhasil dengan mencapai indikator keberhasilan yang ditetapkan. Hal ini dapat dilihat bahwa hasil belajar siswa terhadap pembelajaran matematika pada siklus I belum mencapai kriteria keberhasilan yang telah ditetapkan. Hasil ini dapat dilihat dari hasil perolehan skor pada evaluasi yang berupa tes formatif yang telah diselesaikan oleh siswa dari 24 siswa 9 siswa yang tidak tuntas dan 15 siswa tuntas dengan presentase ketuntasan belajarnya mencapai $62,5 \%$. Sedangkan pada siklus II, presentase ketuntasan telah meningkat dari 24 siswa hanya 4 siswa yang tidak tuntas dan 20 siswa tuntas dengan presentase ketuntasan belajarnya mencapai $83,3 \%$.

\section{SIMPULAN}

Setelah dilakukan pembelajaran dengan menggunakan model pembelajaran Think Pair Share (TPS) dapat meningkatkan hasil belajar siswa tentang penjumlahan dan pengurangan pecahan di kelas IV SD Negeri 14 Biru Kecamatan Tanete Riattang Kabupaten Bone. Hal tersebut dapat dilihat dari hasil belajar siswa yang mengalami peningkatan pada setiap 
siklus.Pada siklus I berada pada kategori cukup (C), sedangkan siklus II meningkat menjadi kategori baik (B).

Pembelajaran dengan menerapkan model Think Pair Share (TPS) dari aspek guru maupun siswa dapat mencapai hasil yang diharapkan dari tindakan ke tahap refleksi dan perbaikan melalui kolaborasi yang baik dengan pihak yang terkait dalam penelitian. Sehingga hasil belajar melalui penerapan model Think Pair Share (TPS) siswa kelas IV SD Negeri 14 Biru Kecamatan Tanete Riattang Kabuoaten Bone telah mengalami peningkatan khususnya pada pembelajaran penjumlahan dan pengurangan pecahan.

\section{REFERENSI}

Aisyah, Nyimas. Siti Hawa. Somakim. Purwoko. Yusuf Hartino dan Masrinawatie. 2008. Pengembanagan Pembelajaran Matematika SD. Direktorat Jendral Pendidikan Tinggi Departemen Pendidikan Nasional

Arikunto, Suharsimi \& Safruddin, Cepi Abdul Jabar. 2009. Evaluasi Program Pendidikan. Jakarta: Bumi Aksara.

Arikunto, Suharsimi., Suhardjono \& Supardi. 2011. Penelitian Tindakan Kelas. Jakarta: Bumi Aksara.

Daryanto. 2011. Penelitian Tindakan Kelas dan Penelitian Tindakan Sekolah. Yogyakarta: Gava Media.

Depdiknas. 2006. Kurikulum Tingkat Satuan Pendidikan (KTSP). Jakarta: Departemen Pendidikan Nasional.

Faturrohman, Pupuh \& Sutikno, Sobry. 2007. Strategi Belajar Mengajar. Bandung: PT. Rafika Aditama.

Huda, Miftahul. 2015. Model-model Pengajaran dan Pembelajaran di Sekolah Dasar. Jakarta: Kencana Prenada Group.

Kunandar. 2008. Penenlitian Tindak Kelas. Jakarta: PT. Raja Grafindo Persada.

Revyareza. 2013. Hakikat Matematika. (Online), http://revyareza.wordpress/2013/10/31/ha kikat-matematika.html?m-1, (diakses 22 Februari 2017 pukul 18.30 WITA).

Ridha. 2013. Hakikat Model Kooperatif Tipe Think.

(Online), http://ridha90.blogspot.co.id/2013/05/haki kat-model-kooperatif-tipe- think.html?m=1, (diakses 25 Juli 2017 pukul 15.28 WITA).

Rusman. 2014. Model-model Pembelajaran. Jakarta: PT. Raja Grafindo Persada.

Satori, Djam'an \& Koomariah. 2009. Metodologi Penenlitian Kualitatif. Bandung: Alfabeta.

Shoimin, Aris. 2014. Model Pemblejaran Inovatif dalam Kurikulum 2013. Yogyakarta: Ar-Ruzz Media.

Suprijono, Agus. 2009. Cooperative Learning: Teori dan Aplikasi PAIKEM. Yogyakarta : Pustaka Pelajar Offset.

Susanto, Ahmad. 2013. Teori Belajar dan Pembelajaran di Sekolah Dasar. Jakarta: Kencana Pradana Group.

Trianto. 2009. Mendesain Model Pembelajaran Inovatif- Progresif. Jakarta: Kencana Pradana Media Group. 